\title{
ANALYSIS OF THE POSSIBILITY OF DISSEMINATING THE “GAME- MOVEMENT-DEVELOPMENT” APPROACH IN EARLY CHILDHOOD EDUCATION
}

\author{
GREGORC JERA ${ }^{1}$, MAJA MEŠKO ${ }^{2}$ \\ ${ }^{1}$ University of Ljubljana, Faculty of Education, Department of Preschool Education, Slovenia \\ ${ }^{2}$ University of Primorska, Faculty of Management, Slovenia
}

Mailing address: Maja Meško, University of Primorska, Faculty of Management, 6000

Koper, Slovenia, tel.: +386056102042, e-mail: maja.mesko@gmail.com

\begin{abstract}
Introduction. The "game-movement-development" (GMD) approach was conceived in the light of contemporary scientific knowledge in the field of kinesiology, neuro-education, pedagogy, and psychology related to the preschool period. The approach has been implemented for over 15 years in a selected kindergarten. The aim of the study was to examine the feasibility of applying the new GMD approach in different kindergartens depending on the children's age and according to selected quality indicators. Material and methods. We employed an experimental pedagogical exploratory method on a sample of 30 preschool teacher assistants who were employed in 30 kindergartens located in Slovenia. The sample also included a group of 512 children, who were divided into two subgroups: 318 (62\%) of them were from an older age group (3-6 years old) and 194 (38\%) of them were from a younger age group (1-3 years old). All the children were involved in a project with the same theme. The educators implemented it according to the principles of the approach presented in the article. Three types of variables were used to determine the effectiveness, advantages, and weaknesses of the approach. Results. A detailed analysis of the projects, semi-structured interviews, and surveys that were completed showed that both age groups adapted quickly to the new approach, especially the younger group of children. Different methods (e.g. that of using educational games), which involve the educator's participation in the game as a team-mate, made it possible for all of the children to be rapidly integrated into the game and to choose how to move within its rules. However, the educators surveyed believed that they lacked knowledge concerning child development and that they needed more time to understand the new approach, more systematic assistance, and immediate feedback. Conclusions. The research showed that the approach was effective in its essence for all age groups of children. The disadvantages of the approach are primarily related to the need to amend teachers' subjective theories of learning, which requires a longer time.
\end{abstract}

Key words: approach, holistic development, preschool period, learning process

\section{Introduction}

An analysis of modern literature in the field of education shows that researchers of different disciplines (kinesiology, psychology, neuro-education, pedagogy, and similar disciplines) highlight the decisive role of proper work with preschool children for their further comprehensive development. In the light of new research approaches (e.g. NTC learning, the Reggio Emilia approach, the approach of recognition, the GMD approach, etc.), modern scientific discoveries have been introduced into education.

The effectiveness of the "game-movement-development" approach is extremely difficult to measure, given the magnitude and dispersion of data available to qualitative researchers. In the following section we will present the ideas underlying the approach and highlight some key criteria that can be used to assess its implementation.

The first idea which is a foundation of the GMD approach is holistic development. The integrity of holistic child development was already stressed by Ismail in 1976 [1]. Videmšek and Pišot [2] claim that different areas of child development (physical, motor, cognitive, emotional, and social) are interrelated in such a way that a change in one area affects the changes in all other areas. It is difficult to measure all aspects of development at the same time, so researchers have examined only two or three aspects simultaneously. They have determined the relations between motor and cognitive development $[3,4,5,6]$, between motor and emotional development [6, 7, 8, 9, 10], and between motor and physical development [11]. In each case they established that the areas were closely interrelated. Accordingly, we have stressed the impossibility of investigating the areas of child development separately. Holistic development is also reflected in the integrity and complexity of particular areas of child development. Pišot and Planinšec [12] established the integrity and complexity in the latent structure of motor abilities, while Vehovar [13] established the complexity and incomplete differentiation of motor abilities in preschool children. Horvat [14] states that the integrity and constantly changing structure of motor abilities during the course of a child's development presents a significant challenge for researchers. From the same perspective, Siegl and Payne Bryso [15] investigated the integrity of brain response in a child and presented several useful exercises impacting various areas of child development.

The second idea which underlies the GMD approach is based on recent research into the positive effects of physical 
activity (various forms of movement) on a child's development $[16,17]$ and the principles of preschool child development. In light of that theory, we have stressed the inseparable link between the development of motor abilities (acquired through various forms of movement) and the whole of child development. Movement is given a key role in the GMD approach, and it should be understood as the way in which children communicate with themselves and the outside world. By moving, children receive their first information, which they process and store in their brains. At first, they start to get to know themselves, and then, they learn about the world around them. Bregant [16] emphasises that physical activity is indispensable for the normal physical development of a child. In addition to this, synapse formation is the most intense in the first years of our lives and depends on physical activity [17]. Based on this information and the fact that a change in one area affects changes in all other areas of child development [2], the theory of the inseparable interrelation between physical activity and general development proves to be accurate.

The third idea behind the GMD approach, which stems from those discussed above, is the need to provide children with opportunities for adequate physical activity. The question is how much and what kind of physical activity is suitable for children in the preschool period. The World Health Organization [18] has adopted higher standards for adequate physical activity for children which is to be beneficial for the healthy physical and mental development of a child. Haug [19] claims that the lifestyle one adopts during their youth is the lifestyle one will have in adult life. Moreover, Zajec [20] has established that children who have physically active parents are more physically active themselves. Kremžar and Petelin [21] have looked at the idea of motor development from the sensorimotor perspective. They argue that physical activity stems from the sensory area. Thus, during the preschool period, motor responses to sensory inputs enable the child's development, although inner motivation to play is required. Therefore, in the design of the approach, special attention was paid to physical activity. Bergant [16] emphasises that physical activity during childhood does not only foster the development of certain skills; it influences the development and maturation of the entire motor and sensory systems and their integration at the level of the central nervous system. Physical activity is thus indispensable for normal child development.

We concluded that holistic child development requires a holistic approach. Therefore, we tried to establish how children's development can be fostered. For this purpose, we followed the latest discoveries regarding the understanding of child development. We began to develop the "game-movement-development" approach by studying traditional and contemporary pedagogical concepts and approaches. However, we applied only selected aspects of the concepts and approaches studied and used the theory of the inseparable interrelation between physical activity and development as well as the theory of holistic development in its broadest sense, in order to overcome the shortcomings of the approach. When developing the approach, we outlined a programme for a process-developmentbased curriculum for kindergartens. The approach is consistent with all the global goals and principles of the curriculum and is based on sensorimotor integration and the inseparable interrelations between game, movement, and development.

We tried to stress the importance of the child's participation in the learning process by developing a teaching method that allows the child to choose and generate the rules and goals of the game, as well as making it possible to decide autonomously about them, within certain boundaries. Thanks to a close connection between game and movement, the approach makes sure that each child's game involves movement, and any movement affects their development as a whole [22]. Batistič
Zorec [23] claims that game is a spontaneous, creative activity that is a part of our lives during different life periods, not only in childhood; however, during the preschool period, game is a predominant activity [22]. Game is therefore an appropriate method of teaching, as long it is properly understood. Educators must take the opportunity to influence the game and take part in it, if they want its objective to be achieved. They can do so by acting as team-mates or taking part in setting the rules. Unguided children's games also have a positive impact on their development, but it is not possible to influence their rules. The educator has to invent a game that will be beneficial for the children, which is possible thanks to the fact that they understand child development (its physical, emotional, cognitive, and social aspects, among others) as a whole. Game is essential for a child's normal development and can involve all the essential elements of learning (agreeableness, intrinsic motivation, revision, open-mindedness, following rules, research, longterm memory, development, etc.). It is an inseparable part of growing up because of a strong emphasis on games and "gamefulness". However, several experts still oppose the idea of introducing games as a predominant activity in kindergartens, because it is easier from the perspective of an educator to use standard methods of teaching, such as explanation or demonstration, than to use games [24].

The main difference between any game and "the game method" is the role of the educator. By taking part in the game, educators can lead the game the way they wish in order to achieve the curriculum goal(s), whereas children play because they want to achieve the goal of the game. As part of the 15-year-long pedagogical study in one kindergarten, we designed different types of games (classical, environmental, improvisational, etc.). All the types of games have goals connected with different areas of the curriculum (e.g. nature, movement, mathematics, etc.), and they have strong and positive connections with at least two different curriculum areas. However, challenges to do with movement should always be the first goal introduced in the game. Children must also have an opportunity to choose or create a type of problem-solving task within the rules of the game. That is why the rules need to be carefully set up. All goals in this study were chosen from several curriculum areas, with the task of building a story with a problem in it. By solving a story problem, the children were to achieve the goals we set within the rules of the game.

Children's play changes during their development because of changes in their cognitive, social, motor, physical, and emotional status. That is why educators working with younger age groups need to construct different types of games, such as games with a changing environment or games of improvisation, covering a number of curriculum areas, goals, etc. It can be predicted that educators in older age groups would tend to do so as a game 'mate', with a role which can influence the process of the game.

The aim of the study is to determine the effectiveness of the approach and its universality in terms of the possibility of introducing such games into all kindergartens irrespective of the approaches being followed or the age of the children. By identifying gaps (weaknesses) in the approach and the method of its dissemination, we would like to prepare suitable solutions and modifications to the approach and to set up a plan for its dissemination.

\section{Material and methods}

We employed an experimental pedagogical exploratory method in a study involving children from 30 kindergartens. The aim of the study was to investigate the feasibility of applying the new "game-movement-development" approach in 
different kindergartens depending on the children's age and according to selected quality indicators.

\section{Sample}

Data for the present analyses were collected for 30 female preschool teacher assistants who were employed in 30 kindergartens located in different parts of Slovenia. All of the teachers had received additional professional education from the Faculty of Education of the University of Ljubljana in Slovenia and were already familiar with the GMD approach, as it had been presented to them during a course in Movement and Intersubject Connections. The average age of the educators was 36.47 ( \pm 6.30 ). They all held at least a university degree in a teaching profession. Half of them worked with 3-6 year-old children, and the other half worked with 1-3 year-old children. The older group included 318 children, and there was one educator per 21 children on average. In the younger group there were 194 children, with one educator per 17 children. All the educators carried out a 5-day learning process according to the GMD approach. In the current research we focused only on the educators who had chosen the game method.

Table 1. Network analysis of the final project based on selected criteria

\begin{tabular}{|c|c|c|c|c|c|c|c|}
\hline Criteria & Solutions & $\begin{array}{r}\text { Num } \\
\text { educa } \\
\text { the } 1 \\
\text { gr }\end{array}$ & $\begin{array}{l}\text { er of } \\
\text { ors in } \\
3 \text { age } \\
\text { up }\end{array}$ & $\begin{array}{r}\text { Num } \\
\text { educa } \\
\text { the } 3 \\
\text { gr }\end{array}$ & $\begin{array}{l}r \text { of } \\
\text { rs in } \\
\text { age } \\
p\end{array}$ & $\begin{array}{r}\text { To } \\
\text { num } \\
\text { educa } \\
\text { both }\end{array}$ & $\begin{array}{l}\text { al } \\
\text { er of } \\
\text { ors in } \\
\text { oups }\end{array}$ \\
\hline \multirow{3}{*}{$\begin{array}{l}\text { Choice of } \\
\text { roles in } \\
\text { the game }\end{array}$} & \multirow{3}{*}{$\begin{array}{c}\text { Educator led the } \\
\text { game by taking } \\
\text { an appropriate } \\
\text { role }\end{array}$} & $\begin{array}{l}\text { Partici- } \\
\text { pation } \\
\text { in rule } \\
\text { determi- } \\
\text { nation }\end{array}$ & $\begin{array}{l}\text { Partici. } \\
\text { pation } \\
\text { in the } \\
\text { game }\end{array}$ & $\begin{array}{l}\text { Partici- } \\
\text { pation } \\
\text { in rule } \\
\text { determi- } \\
\text { nation }\end{array}$ & $\begin{array}{l}\text { Partici- } \\
\text { pation } \\
\text { in the } \\
\text { game }\end{array}$ & $\begin{array}{l}\text { Partici- } \\
\text { pation } \\
\text { in rule } \\
\text { determi- } \\
\text { nation }\end{array}$ & $\begin{array}{l}\text { Partici- } \\
\text { pation } \\
\text { in the } \\
\text { game }\end{array}$ \\
\hline & & $\begin{array}{l}{ }^{* *} f \\
(\%)\end{array}$ & $\begin{array}{l}{ }^{* *} f \\
(\%)\end{array}$ & $\begin{array}{l}{ }^{* *} f \\
(\%)\end{array}$ & $\begin{array}{l}*_{f}^{*} \\
(\%)\end{array}$ & $\begin{array}{l}{ }^{* * f} f \\
(\%)\end{array}$ & $\begin{array}{l}*_{f}^{*} \\
(\%)\end{array}$ \\
\hline & & $\begin{array}{c}11 \\
(73)\end{array}$ & $4(27)$ & $3(20)$ & $\begin{array}{c}12 \\
(80)\end{array}$ & $\begin{array}{c}14 \\
(47)\end{array}$ & $\begin{array}{c}16 \\
(53)\end{array}$ \\
\hline \multirow{4}{*}{$\begin{array}{l}\text { Super- } \\
\text { structure } \\
\text { of game } \\
\text { content } \\
\text { and } \\
\text { inclusion } \\
\text { of various } \\
\text { curriculum } \\
\text { areas }\end{array}$} & \multirow{2}{*}{$\begin{array}{c}\text { Game content } \\
\text { (Likert scale } \\
1.5)^{*}\end{array}$} & M & SD & M & SD & M & SD \\
\hline & & 4.00 & 0.85 & 3.53 & 0.99 & 3.77 & 0.94 \\
\hline & \multirow{2}{*}{$\begin{array}{l}\text { Inclusion of cur- } \\
\text { riculum areas } \\
\text { (Likert scale } \\
1-5)^{*}\end{array}$} & M & SD & M & SD & M & SD \\
\hline & & 4.27 & 0.70 & 3.13 & 0.83 & 3.70 & 0.95 \\
\hline \multirow{2}{*}{$\begin{array}{l}\text { Enabling } \\
\text { the child } \\
\text { to move } \\
\text { and be } \\
\text { creative }\end{array}$} & \multirow{2}{*}{$\begin{array}{l}\text { The rules of the } \\
\text { game allow the } \\
\text { child to choose } \\
\text { a type of move- } \\
\text { ment and solve } \\
\text { a problem in a } \\
\text { creative way } \\
\text { (Likert scale } \\
1-5)^{*}\end{array}$} & M & SD & M & SD & M & SD \\
\hline & & 4.47 & 0.52 & 3.13 & 0.99 & 3.80 & 1.03 \\
\hline
\end{tabular}

${ }^{*}-1$ = poor, 5 = excellent, ${ }^{* *} f(\%)-$ frequency distribution.

\section{Sources of data}

Three different sources of qualitative data were used in the study. The first source was a finished product (network analysis connected with 5-day learning processes) recorded by the educators after the completion of the projects. The criteria used in the analysis of the teachers' performance were based on the following factors:

- adequate choice of roles in the game,
- adequate superstructure of game content and inclusion of various curriculum areas,

- choice of an appropriate game which enables the child to move and be creative.

The second source was an informal semi-structured interview with the educators that included questions on the usefulness of the approach, its deficiencies, and any problems the educators encountered. Selected criteria that were used in order to determine the universality of the approach were the following:

- the approach can be combined with various other educational approaches,

- the approach can be smoothly combined with the educational approach currently being implemented by the kindergarten,

- the approach requires a change in teachers' attitudes towards learning.

The third source of data was a questionnaire completed by the educators during and after the completion of the process. The questions were close-ended and related to the entire research study.

\section{Processing of results}

The qualitative data were processed using network and thematic analysis. We compared the data with the results of the longitudinal case study. The quantitative data were processed using the statistical package SPSS 20.0 for Windows. The "Frequencies" command was used to calculate the frequency of individual answers, and the "Descriptives" command was used to calculate descriptive statistics. We also performed cross-tabulations, calculated bivariate correlation coefficients, as well as conducting t-tests and ANOVA analyses in order to test our hypotheses. The hypotheses were tested at the 0.05 level of significance.

\section{Results}

The results will be presented according to the established criteria and grouped according to the type of variable and data collection method. The qualitative results will be presented in the form of an in-depth network and thematic analysis of the educators' finished products, and the quantitative results will be presented in tables.

Table 1 shows how well the educators implemented the approach in practice. We can see that $73 \%$ of the educators of younger groups impacted the game by influencing its rules, while only $20 \%$ of the educators working with older groups did so. The content of the games the teachers used was of average quality (3.77). Educators who teach younger children received higher scores for the two performance criteria (more than 4 points on the Likert scale). As far as enabling children to have a choice in solving the movement problem and select various solutions to the same problem, the educators of the older groups met this criterion less often than those of the younger groups.

On the basis of the results of the study presented in table 2, which shows some data collected in the semi-structured interviews and discussions with the educators, it can be concluded that the educators thought it was possible to combine this approach with various other approaches, especially in younger groups. However, all of the teachers, and particularly the educators of younger groups, said they needed to change their attitudes towards learning. They found its implementation difficult for different reasons, which were mostly subjective, such as their insufficient comprehension of the approach. Other educators believed that the approach could be applied only in certain groups, especially in groups where the teachers 
Table 2. Testing the differences between educators of younger and older groups of children indicated by semi-structured thematic interview

\begin{tabular}{|c|c|c|c|c|c|c|}
\hline \multirow{2}{*}{$\begin{array}{l}\text { Selected criteria } \\
\text { regarding the } \\
\text { usefulness of the } \\
\text { approach }\end{array}$} & \multirow{2}{*}{ Group } & \multirow{2}{*}{$\mathbf{N}$} & \multirow{2}{*}{$\mathbf{M}$} & \multirow{2}{*}{ SD } & \multicolumn{2}{|c|}{ ANOVA } \\
\hline & & & & & $\mathbf{F}$ & p \\
\hline \multirow{3}{*}{$\begin{array}{c}\text { The approach can be } \\
\text { combined with various } \\
\text { other educational ap- } \\
\text { proaches. (Likert scale } \\
1-5)^{*}\end{array}$} & Younger & 15 & 4.47 & 0.834 & \multirow{3}{*}{20.884} & \multirow{3}{*}{0.000} \\
\hline & Older & 15 & 3.20 & 0.676 & & \\
\hline & Total & 30 & 3.83 & 0.986 & & \\
\hline \multirow{3}{*}{$\begin{array}{l}\text { The approach can be } \\
\text { smoothly combined } \\
\text { with the educational } \\
\text { approach currently } \\
\text { being implemented by } \\
\text { the kindergarten. (Likert } \\
\text { scale } 1-5)^{*}\end{array}$} & Younger & 15 & 3.73 & 0.594 & \multirow{3}{*}{18.484} & \multirow{3}{*}{0.000} \\
\hline & Older & 15 & 4.60 & 0.507 & & \\
\hline & Total & 30 & 4.17 & 0.699 & & \\
\hline \multirow{3}{*}{$\begin{array}{l}\text { The approach requires } \\
\text { a change in teachers' } \\
\text { attitudes towards } \\
\text { learning. } \\
\text { (Likert scale 1-5)* }\end{array}$} & Younger & 15 & 3.87 & 0.743 & \multirow{3}{*}{3.500} & \multirow{3}{*}{0.072} \\
\hline & Older & 15 & 4.33 & 0.617 & & \\
\hline & Total & 30 & 4.10 & 0.712 & & \\
\hline
\end{tabular}

* $-1=$ statement is completely false, $5=$ statement is completely true.

Table 3. Differences between the opinions of educators of younger and older groups on selected statements related to implementing the theoretical approach in practice (obtained in the questionnaire)

\begin{tabular}{|c|c|c|c|c|c|c|}
\hline \multirow{2}{*}{$\begin{array}{l}\text { Selected state- } \\
\text { ments }\end{array}$} & \multirow{2}{*}{ Group } & \multirow{2}{*}{$\mathbf{N}$} & \multirow{2}{*}{$\mathbf{M}$} & \multirow{2}{*}{ SD } & \multicolumn{2}{|c|}{ ANOVA } \\
\hline & & & & & $\mathbf{F}$ & p \\
\hline \multirow{3}{*}{$\begin{array}{l}\text { Physical activity is im- } \\
\text { portant for normal and } \\
\text { healthy child develop- } \\
\text { ment. (Likert scale } 1-5)^{*}\end{array}$} & Younger & 15 & 5.00 & 0.000 & \multirow{3}{*}{1} & \multirow{3}{*}{1} \\
\hline & Older & 15 & 5.00 & 0.000 & & \\
\hline & Total & 30 & 5.00 & 0.000 & & \\
\hline \multirow{3}{*}{$\begin{array}{l}\text { The GMD approach } \\
\text { gives priority to learning } \\
\text { over teaching. (Likert } \\
\text { scale } 1-5)^{*}\end{array}$} & Younger & 15 & 4.80 & 0.414 & \multirow{3}{*}{0.175} & \multirow{3}{*}{0.679} \\
\hline & Older & 15 & 4.73 & 0.458 & & \\
\hline & Total & 30 & 4.77 & 0.430 & & \\
\hline \multirow{3}{*}{$\begin{array}{l}\text { The game method is a } \\
\text { child-based teaching } \\
\text { method which requires } \\
\text { a transition from the } \\
\text { traditional way of } \\
\text { teaching to teaching } \\
\text { through game. (Likert } \\
\text { scale } 1-5)^{*}\end{array}$} & Younger & 15 & 4.53 & 0.516 & \multirow[b]{3}{*}{0.100} & \multirow[b]{3}{*}{0.754} \\
\hline & Older & 15 & 4.60 & 0.632 & & \\
\hline & Total & 30 & 4.57 & 0.568 & & \\
\hline \multirow{3}{*}{$\begin{array}{l}\text { The GMD approach } \\
\text { enables children to } \\
\text { actively participate in } \\
\text { the learning process, } \\
\text { have freedom, and take } \\
\text { decisions, while the } \\
\text { teacher can pursue the } \\
\text { goal of the approach. } \\
\text { (Likert scale 1-5)* }\end{array}$} & Younger & 15 & 4.67 & 0.488 & \multirow[b]{3}{*}{0.000} & \multirow[b]{3}{*}{1.00} \\
\hline & Older & 15 & 4.67 & 0.488 & & \\
\hline & Total & 30 & 4.67 & 0.479 & & \\
\hline
\end{tabular}

* $-1=$ statement is completely false, $5=$ statement is completely true. had adopted a different approach and were willing to change together with the children. However, they were aware that they needed more expertise and more time to be able to plan the implementation of the new approach properly.

On the basis of table 3, it can be stated that all of the educators surveyed considered physical activity crucial for the normal development of a child, and there were no differences between the subgroups of educators with regard to this issue. Based on the questionnaire, we have also established that they were able to realise that the approach enables them to establish the priority of learning over teaching. They were able to implement a process-development-based curriculum, with no differences noted between the subgroups of educators. The educators defined the game method as a child-based teaching method that requires a change in the traditional way of teaching. The last selected statement follows as a logical result; the educators confirmed that the approach enables children to actively participate in the learning process and to have freedom, while allowing teachers to pursue their educational goals. There were no statistical differences between the subgroups of educators. It can be concluded that in the teachers' opinion, the approach has no faults from a theoretical perspective; however, some difficulties in implementing it in practice were experienced, as illustrated in table 1.

Table 4. Differences between educators of younger and older groups in their opinions concerning the effectiveness of the GMD approach in preschool education before the beginning of the project, after the first learning unit, and at the end of the project

\begin{tabular}{|c|c|c|c|c|c|c|}
\hline \multirow{2}{*}{$\begin{array}{c}\text { Stage of the imple- } \\
\text { mentation of the } \\
\text { project }\end{array}$} & \multirow{2}{*}{ Group } & \multirow{2}{*}{$\mathbf{N}$} & \multirow{2}{*}{ M } & \multirow{2}{*}{ SD } & \multicolumn{2}{|c|}{ ANOVA } \\
\hline & & & & & $\mathbf{F}$ & p \\
\hline \multirow{3}{*}{$\begin{array}{l}\text { Stage 1: After the pres- } \\
\text { entation of the theory } \\
\text { (Likert scale 1-5)* }\end{array}$} & Younger & 15 & 4.13 & 0.743 & \multirow{3}{*}{1.287} & \multirow{3}{*}{0.266} \\
\hline & Older & 15 & 3.80 & 0.862 & & \\
\hline & Total & 30 & 3.97 & 0.809 & & \\
\hline \multirow{3}{*}{$\begin{array}{l}\text { Stage 2: After the first } \\
\text { learning unit (Likert } \\
\text { scale } 1-5)^{*}\end{array}$} & Younger & 15 & 4.33 & 0.617 & \multirow{3}{*}{1.522} & \multirow{3}{*}{0.228} \\
\hline & Older & 15 & 4.00 & 0.845 & & \\
\hline & Total & 30 & 4.17 & 0.747 & & \\
\hline \multirow{3}{*}{$\begin{array}{c}\text { Stage 3: At the end of } \\
\text { the project (Likert scale } \\
1-5)^{*}\end{array}$} & Younger & 15 & 4.93 & 0.258 & \multirow{3}{*}{13.176} & \multirow{3}{*}{0.001} \\
\hline & Older & 15 & 4.40 & 0.507 & & \\
\hline & Total & 30 & 4.67 & 0.479 & & \\
\hline
\end{tabular}

1 - the GMD approach is not an effective learning method in preschool education; 5 - the GMD approach is an effective learning method in preschool education.

Table 4 shows how the educators perceived the effectiveness of the GMD approach as a learning method in preschool education on a five-point Likert scale, according to the different stages of the transition from theory to practice. It can be observed that there are differences between particular stages and subgroups of teachers. The differences between the subgroups were tested using ANOVA. Statistically significant differences were noticed in the third stage between educators of different age groups. The educators of younger groups saw the method as more effective than did those working with older groups.

Furthermore, the differences between the stages were proven to be statistically significant using a t-test. The independent $\mathrm{t}$-test showed statistically significant differences $(\mathrm{t}=2.4, \mathrm{p}=$ 0.00 ) between the variables after the presentation of the theory (1) and at the end of the project (3), regardless of the subgroup. 
The correlation between the variables was also tested using Pearson's correlation coefficient, and it was statistically significant at the 0.05 level of significance.

Table 5. The teachers' attitude towards the continuous development of their professional expertise and the frequency of their own physical activity

\begin{tabular}{|c|c|c|c|}
\hline & & \multicolumn{2}{|c|}{ Frequency of physical activity } \\
\hline & & $\begin{array}{l}\text { Insufficient } \\
\text { for healthy } \\
\text { lifestyle }\end{array}$ & $\begin{array}{l}\text { Sufficient } \\
\text { for healthy } \\
\text { lifestyle }\end{array}$ \\
\hline \multirow{2}{*}{$\begin{array}{l}\text { Attitude to continu- } \\
\text { ous improvement } \\
\text { of professional } \\
\text { expertise }\end{array}$} & $\begin{array}{l}\text { I do not wish to } \\
\text { improve my profes- } \\
\text { sional expertise. }\end{array}$ & $4(40 \%)$ & $6(30 \%)$ \\
\hline & $\begin{array}{l}\text { I wish to improve } \\
\text { my professional } \\
\text { expertise. }\end{array}$ & $6(60 \%)$ & $14(70 \%)$ \\
\hline $\begin{array}{l}\text { Total (for } 30 \text { educa- } \\
\text { tors) }\end{array}$ & & $10(100 \%)$ & $20(100 \%)$ \\
\hline
\end{tabular}

Table 5 shows that the educators who are not interested in continually developing their professional expertise were more numerous among those whose lifestyles lacked sufficient physical activity. Among 30 educators, 33.3\% (10 of 30) lacked an amount of physical activity which would make it possible for them to maintain a healthy lifestyle. Forty percent of these teachers believed that they did not need to continually improve their professional expertise. Among those who declared that they were sufficiently physically active $(66.6 \%$ of 30 educators), only a third would not consider improving their expertise. The results were also examined using a chi-square test. However, the test showed no statistically significant differences between the variables.

\section{Discussion}

We developed the "game-movement-development" approach in order to make use of new scientific knowledge in kinesiology, psychology, neuro-education, pedagogy, and similar fields, on the one hand, and to offer a new curriculum, on the other. The curriculum based on the GMD approach puts educators in a different position by enabling children to actively participate in the learning process, have freedom, and take decisions, while the educators are able to pursue the goals of the approach. That is why we thought it necessary to examine the value of traditional forms of teaching (demonstration, explanation, etc.) and general issues having to do with teaching. We proposed a "game method", which seemed to be a valid solution in theory. As it had only been implemented in one kindergarten, we needed to find out whether the whole approach (not only the method of teaching) could be implemented in all educational programmes.

To ascertain the suitability of our approach for kindergartens that implement different educational programmes, we used an experimental pedagogical exploratory method. The main aim of the research was to establish the effectiveness of the theory in practice. We conducted action research, studying 30 examples of projects based on our approach.

After 30 educators were trained for 50 hours, they developed a 5-day learning process following the GMD approach, taking into account their own materials, personnel, organization and content. The project was implemented in 30 kinder- gartens around Slovenia. After finishing the project, we conducted a detailed analysis of the effects of its implementation by educators from different kindergartens and working with various age groups, who also collaborated with us by participating in open semi-structured interviews and filling in a questionnaire.

We would like to highlight three findings. The first is the teachers' success in planning the educational process after 50 hours of training, which we measured by assessing selected criteria mentioned above, such as taking an appropriate role in the game and setting appropriate goals. There were no significant educational or experiential differences between educators who taught younger and older age groups. However, the average values attributed to all of the selected criteria were approximately 3 points. That means that becoming well trained in using the approach requires a longer training programme and some changes within the programme; thus, contrary to what had been expected, 50 hours of training were insufficient for the teachers to master the approach. The main source of difficulty in mastering the approach lay in the teachers' subjective theories. Batistič Zorec [25] states that subjective theories change very slowly. She believes that these theories are key for modernising any aspect of the curriculum and that comprehension, experience, and the use of new methods are fundamental to implementing a different kind of approach. We need to extend the period of training in our approach and provide educators more practical experience with feedback. We also noted that the educators did not pay proper attention to child development and the special characteristics of particular groups. Poor knowledge in the area of identifying child development phases was also ascertained by Gregorc and Cemič [24]. Such poor knowledge results in "educators' instinctive reactions". Nevertheless, teachers are frequently successful, even if they lack theoretical knowledge.

The second important finding is the usefulness of the approach for all kindergartens, regardless of the existing approach or age group being taught. We noticed that a short project can be smoothly implemented, but there are still some difficulties in permanent implementation. Through semi-structured interviews, some of which are presented in table 2, we learned that the approach requires a great deal of expertise, patience, and continuous training. The educators found the GMD approach effective in preschool education, but they could not start implementing it mostly due to subjective reasons related to the knowledge or expertise of other participants (educators) in their kindergarten. The educators stated that both they and the children had to adopt the approach step by step. The semistructured interviews showed that the children were faster to adopt the game approach and they "forgave" the mistakes of educators who had difficulties in accepting the priority of learning over teaching and children's increased participation. If these changes are to be accepted, the teachers' point of view needs to change, as claimed by Turnšek, Hodnik Čadež, and Krnel [26]. However, they believe further professional training is required to achieve this.

The third finding we would like to emphasise concerns the teachers' attitude towards the continuous development of their professional expertise and the frequency of their own physical activity, given the required change in subjective theories, which are the key for implementing a new approach [25]. Our research did not confirm that the educators were explicitly aware of the importance of continuous professional training. They stressed the key role of the immediate environment (especially of preschool teachers, preschool teachers' assistants, and parents) in the development of the child's behavioural style and consequently, the quality of life of an individual [27, 28, $29,30]$, and this suggests that their subjective theories affect their teaching styles [31]. We anticipated that there would be 
a connection between the lifestyle of the educators (especially their physical activity) and their attitude to additional professional training; however, the chi-square test found no statistically significant differences among the groups (tab. 5).

\section{Conclusion}

The "game-movement-development" approach was started in 2000 as a project, and continued to develop until it become a new educational approach, or theory. We believe that implementing this new theory is our duty. That is why we aimed to establish whether the theoretical approach, which is childbased and stems from new findings in different fields of science, can already be successfully implemented in other kindergartens or whether any modifications should be made.

One of our aims was also to determine what kinds of problems can arise while implementing such a new approach. The research confirmed that the approach can be implemented in various kindergartens (irrespective of the materials, curriculum areas, and personnel available, and organisational factors), but if the approach is to be implemented in its entirety, teachers and their schools should be better prepared for its implementation. The main reason why implementing the approach successfully takes considerable time is the difficulty in changing the subjective theories about teaching and learning held by those who educate children in the preschool period.

\section{Literature}

1. Ismail A.H. (1976). Integration development: Theory and experimental results. Kineziologija 6(1-2), 7-28. [in Croatian]

2. Videmšek M., Pišot R. (2007). Sport for children. Ljubljana: Fakluteta za šport, Inštitut za šport. [in Slovene]

3. Cotič M., Zurc J., Kozlovič D. (2004). A holistic teaching approach in early education - the role of physical activity in mathematics. Didactica Slovenica 19(2), 32-46.

4. Pišot R., Zurc J. (2003). Influence of out-of-school sports/ motor activity on school success. Kinesiologia Slovenica 9(1), 42-54.

5. Thun-Hohenstein L., Largo R.H., Molinari L., Kundu S., Duc G. (1991). Early fine motor and adaptive development in high-risk appropriate for gestational age preterm and healthy term children. European Journal of Pediatrics 150(8), 562-569.

6. Zaichkowsky L.D., Zaichkowsky L.B., Martinek T.J. (1980). Growth and Development: The Child and Physical Activity. St. Louis, Toronto, London: The C. V. Company.

7. Planinšec J., Fošnarič S., Pišot R. (2004): Physical self-approach and physical exercise in children. Studia Psychologica 46(2), 89-95.

8. Fagot B.I., Obrien M. (1994). Activity level in young-children - cross-age stability, situational influences, correlates with temperament, and the perception of problem behaviours. JSTOR: Merril Palmer Quarterly 40(3), 378-398.

9. Walker N.R. (1992). The Gesell Development Assessment: Psychometric properties. Early Childhood Research Quarterly 7(1), 21-43.

10. Graziano W.G., Jensen-Campbell L.A., Sullivan-Logan G.M. (1998). Temperament, activity, and expectations for later personality development. Journal of Personality and Social Psychology 74(5), 1266-1277.

11. Bala G., Popovič B., Jakšić D. (2009). Trend of changes of general motor ability structure in pre-schoolchildren. In M. Mikalacki (ed.), Proceedings Book of 1st International
Scientific Conference Exercise and Quality of Life (pp. 113118). Novi Sad: Faculty of Sport and Physical Education.

12. Pišot R., Planinšec J. (2005). Structure of motor abilities in early childhood. Koper: Inštitut za kineziološke raziskave, Univerza na Primorskem, Znanstveno-raziskovalno središče Koper.

13. Vehovar M. (2009). Physical dimensions of structure with selected impairments, five and a half children. Master's thesis, University of Ljubljana: Faculty of Sport.

14. Horvat V. (2011). Latent Structure of Motor Abilities in PreSchool Children. US-China Education Review A 6, 781-790.

15. Siegel D.J., Payne Bryson T. (2011). The Whole-Brain Child: 12 Revolutionary Strategies to Nurture Your Child's Developing Mind. New York: Mind Your Brain, Random House.

16. Bregant T. (2010). Brain Development. Proteus 73(4), 168174. [in Slovenian]

17. Burns T. (2011). The brain is a muscle that needs to be strengthened. Dnevnik, 9.4.2011, interview. Retrieved October 4th, 2013, from http://www.dnevnik.si/objektiv/intervjuji/1042436769 [in Slovenian]

18. World Health Organization: Physical activity and young people. Retrieved October 4, 2014, from http://www.who. int/dietphysicalactivity/factsheet_young_people/en/

19. Haug E., Rasnussen M., Samdal O., Iannotti R., Kelly C., Borraccino A. (2009). Overweight in school-aged children and its relationship with demographic and lifestyle factors: Results from the WHO-Collaborative Health Behaviour in School-aged Children (HBSC). Study. International Journal of Public Health Science 54(2), 167-179.

20. Zajec J. (2009). The Sports Activities of Preschool Children and of Their Parents and Selected Factors of Healthy Living. (Unpublished doctoral dissertation). University of Ljubljana, Faculty of Sport, Slovenia. [in Slovenian]

21. Kremžar B., Petelin M. (2001). The child's physical behaviour. Ljubljana, Slovenia: Društvo za motopedagogiko in psihomotoriko. [In Slovenian]

22. Cemič, A. (2004). Analysis of the curriculum by introducing the approach of game-movement and development in the Daisy kindergarten. In R. Pišot, V. Štemberger (eds), Child in motion (Elec. iss.), Koper: University of Primorska, Science and Research Centre. [in Slovenian]

23. Batistič Zorec, M. (2002). Psychological aspects of children's games. Retrieved October 4, 2013, from http://www. pef.uni-lj.si/ vilic/gradiva/1-rp-t4-igra.doc [in Slovenian]

24. Gregorc J., Cemič A. (2013). Freedom of games and playfulness in the autonomy of planning the curriculum in kindergarten. In M. Brejc, P. Weissbacher (eds), Vodenje učenja: zbornik povzetkov (pp. 121-134). Kranj, Slovenia: Šola za ravnatelje. [In Slovenian].

25. Batistič Zorec (2004). Subjective theories of teachers and curriculum renovation in kindergartens. Journal of Contemporary Educational Studies 1(2), 90-101.

26. Turnšek N., Hodnik Čadež T., Krnel D. (2009). The project approach as a strategy for promoting children's participation in learning and creating a better livelihood in kindergarten. In T. Devjak, D. Skubic (eds), The challenges of teaching approach Reggio Emilia (pp. 209-233). Ljubljana: Faculty of Education.

27. Makuc N., Videmšek M, Štihec J. (2010). Enrolling 6-8 year old children in alpine skiing courses in Slovenia. Acta Univeritatis Palackianae Olomucensis Gymnica 40(1), 15-22.

28. Plomin R., Chipuer H.M., Neiderhiser J.M. (1994). Behavioral genetic evidence for the importance of nonshared environment. In E.M. Hetherington, D. Reiss, R. Plomin (eds), Separate social worlds of siblings: The impact of nonshared environment on development (pp. 1-31). Hillsdale, New Jersey: Erlbaum. 
29. Pišot R., Kropej V.L., Završnik J., Zurc J., Strel J. (2005). Child's spare time in the context of gender and environment. In T. Moris (ed.), Promoting Health and Performance for Life (pp. 1-4). Sydney: International Society of Sport Psychology.

30. Pišot R., Kropej V.L. (2005). Relations between physical activity, lifestyle and life quality indices of children and youth. In J. Novotný (ed.), Sport a kvalita života: sborníkčlánků a abstraktmezinárodní konference konané $v$ Brne (pp. 1-16). 10th-11th November 2005 in Brno, Brno: Masarykova Univerzita.

31. Gregorc J., Videmšek M., Štihec J., Karpljuk D., Tušak M., Meško M. (2012). The lifestyle of pre-school teachers and their assistants as an element of subjective theories. Slovenian Journal of Public Health 51(2), 95-104.

Submitted: March 10, 2015

Accepted: July 20, 2015 